\title{
Crime among irregular immigrants and the influence of internal border control
}

\author{
Arjen Leerkes - Godfried Engbersen • \\ Joanne van der Leun
}

Published online: 16 February 2012

(C) The Author(s) 2012. This article is published with open access at Springerlink.com

\begin{abstract}
Both the number of crime suspects without legal status and the number of irregular or undocumented immigrants held in detention facilities increased substantially in the Netherlands between 1997 and 2003. In this period, the Dutch state increasingly attempted to exclude irregular immigrants from the formal labour market and public provisions. At the same time the registered crime among irregular migrants rose. The 'marginalisation thesis' asserts that a larger number of migrants have become involved in crime in response to a decrease in conventional life chances. Using police and administrative data, the present study takes four alternative interpretations into consideration based on: 1) reclassification of immigrant statuses by the state and redefinition of the law, 2) criminal migration and crossborder crime, 3) changes in policing, and 4) demographic changes. A combination of factors is found to have caused the rise in crime, but the marginalisation thesis still accounts for at least $28 \%$. These findings accentuate the need for a more thorough discussion on the intended and unintended consequences of border control for immigrant crime.
\end{abstract}

\section{Introduction}

Governments on both sides of the Atlantic are increasingly relying on practices of internal border control to discourage unwanted migrants from settling without

A. Leerkes $\cdot$ G. Engbersen

Sociology Department, Erasmus University Rotterdam, Rotterdam, the Netherlands

A. Leerkes

e-mail: leerkes@fsw.eur.nl

G. Engbersen

e-mail: engbersen@fsw.eur.nl

A. Leerkes

Research and Documentation Centre ('WODC'), Dutch Ministry of Justice, The Hague, the Netherlands

J. van der Leun $(\bowtie)$

Leiden Law School, Criminology, Leiden University, Steenschuur 25,

NL 2311 ES Leiden, the Netherlands

e-mail: j.p.vanderleun@law.leidenuniv.nl 
government consent $[3,28,42,67]$. This is true for various EU countries in particular, where the importance of national borders has diminished as a result of the Schengen Agreement, and national governments have begun to look for alternatives to control unwanted immigration [11]. There has also been an expansion of migration control 'to the inside' in the US, both at the federal level and, especially since 2005, at the state level [63]. Internal border control takes place within state territory and can be distinguished from external border control (patrolling of territorial borders, visa systems). There are two main types of internal control [37]. The first type is aimed at excluding illegally residing or undocumented immigrants (hereafter: irregular immigrants) from the welfare state's key institutions, such as the formal labour market, social security benefits, public education, the formal housing market, and health care. The second type pertains to all practices aimed at tracing and expelling irregular immigrants who have settled in the state territory. This article focuses on the first type of internal border control.

The Netherlands was among the first countries to gradually build up a systematic policy of excluding irregular immigrants from the labour market and public provisions [59]. During the 1960s, when demand for low-skilled labour was high, the Dutch state showed considerable leniency in admitting irregular immigrants, who could quite easily obtain a residence permit after having found employment. After the early 1970s, the policy discourse became more restrictive, but in practice it remained fairly easy for irregular immigrants to acquire social security numbers and find taxpaying jobs in certain sectors. In the early 1990 s, irregular residence came to be seen as a pressing social problem requiring firmer state intervention. At the time, the problem was mostly framed in socio-economic terms. Illegal residence was believed to be a threat to the welfare state, which had come under much financial pressure in the 1980s, and the diminishing border controls within the Schengen area aggravated these concerns. ${ }^{1}$ In 1991, the government barred the use of social security numbers for irregular immigrants, which severely limited their opportunities to work in the formal labour market [60]. Later, in 1998, the 'Linking Act' was implemented, which excluded irregular immigrants from a wide array of public services, including welfare, public housing, education, and (most) health care. It was made obligatory for government and semi-government services, such as welfare departments and housing associations, to check whether their clients are lawful residents and hence are entitled to certain services or benefits [50,57]. Finally, the national government increasingly allocated resources to enforce employer sanctions on employers who hire irregular immigrants informally. ${ }^{2}$ In recent years, i.e. after the period that is central in this article, the Dutch government has taken many more steps to exclude irregular immigrants, and has laid more emphasis on the second type of internal control, i.e. at tracing and attempting to expel irregular immigrants.

One of the aims of the increase in internal border control was to discourage irregular residence. Yet, there are no indications that the policies mentioned have led to a substantial decrease in irregular residence in the Netherlands. Until 2003, the

\footnotetext{
${ }^{1}$ In the literature the term 'internal border control' is sometimes used to refer to external border control of countries within the Schengen area. It should be noted that in this article the term is used differently.

${ }^{2}$ Between 1997 and 2003 the annual budget of the Labour Inspectorate, the responsible body which falls under the Ministry of Social Affairs and Employment, has risen by almost 50\%. Expenditures increased from $€ 39$ million to $€ 56$ million $[35,36]$.
} 
estimated number of irregular immigrants fluctuated between 150,000 and 200,000, or about $1 \%$ of the total population [41]. If a trend can be discerned for this period, it appears to be upwards rather than downwards. It was only after the EU expansion in 2004 that irregular residence diminished to about 130,000 , mostly because immigrants from various new member states could now come to stay in a legal manner [59].

Simultaneously, the period 1997 to 2003 was marked by an increase in the number of crime suspects and detainees without legal status. In 1997, 31\% of all apprehensions by the police and controlling agencies involving irregular immigrants were related to crime rather than to immigration offences or misdemeanours [41]. By April 2004 this share had increased to 49\% [8]. Furthermore, between 1997 and 2004 the number of irregular immigrants held in administrative detention (awaiting expulsion) rose by $92 \%$, and the number of foreigners held in Dutch prisons increased by $49 \%$ [39]. ${ }^{3}$ The latter increase was caused by several factors which are not all discussed here, but the rise in crime suspects without legal status is likely to be among them. Irregular immigrants have elevated detention chances in case of police contacts, and tend to be detained in immigration detention in case of relatively minor crimes that are normally punished with a fine or a Community Punishment Order [61].

There are reasons to believe that the increase in internal border control and the rise in crime are related. Dutch research since the mid-1990s has continuously found that irregular immigrants risk being pushed towards subsistence crime and drug-related crime if they find themselves in a highly marginal social position. The intensification of internal border control may have resulted in a higher prevalence of these types of crime, because more irregular immigrants risk ending up in such a highly marginal position if they stay in the country.

This marginalisation thesis - the idea that social marginalisation may press irregular immigrants to crime-is based on qualitative studies and cross-sectional quantitative studies [23, 24]. In order to make a stronger claim of causality, however, alternative explanations for the rise in crime should be taken into consideration and should be controlled for. This is the aim of the present article. The alternative explanations are taken from the literature and from public debates on irregular migration.

With a broader theoretical perspective and stronger empirical basis, this article aims to contribute to the literature on the intended and unintended effects of border control in two main ways. Firstly, it shows that internal border control, like all policies attempting to curb irregular migration, may have side effects or even perverse effects. So far, most of these consequences, such as the rise in human smuggling, are primarily discussed in relation to external border control [13, 14, 16, 52]. Secondly, we demonstrate that practices of internal control may have consequences for migrant behaviour. There is a substantial literature on the 'securitisation of migration', which analyses how and why political entrepreneurs, security organisations and the media portray certain migration flows as a security threat $[4-7,31,32]$. This literature tends

\footnotetext{
${ }^{3}$ On 30 September 1997 there were 6,105 foreign-born prisoners; on 30 September 20049,125 . This increase had several causes, such as the increased repression of drug trafficking. The number of persons in Aliens' Detention, however, almost doubled in this period: on September 30, 1997, 425 persons were in Aliens' Detention, on 30 September 2004, 1,655. Source: CBS Statline (http:/statline.cbs.nl), visited April 2009.
} 
to focus on the ways in which migrants and migration have come to be constructed as criminal by the law, or are treated as criminal by law enforcement agencies. For example, as Huysmans has claimed: "Once turned into a security problem, the migrant appears as the other who has entered (or who desires to enter) a harmonious world and just by having entered it, has disturbed the harmony"[31: 59]. Likewise Stumpf, in her discussion of what she calls 'crimmigration', has shown that migration policy and criminal law have increasingly merged in the United States: "Immigration violations previously handled as civil matters are increasingly addressed as criminal offenses" [54: 12]. Although we agree that such social constructions may certainly contribute to an-if only 'nominal'-association between immigration and crime, our main concern here is that practices of internal border control may have consequences for the real involvement of irregular migrants in common crimes, such as theft and drug dealing, the definition of which has not changed in recent years. More generally, we aim to contribute to key debates in the study of immigration and crime by arguing that policies of border control should be taken into consideration when explaining immigrant crime. From a policy perspective this article sheds light on the complexities of controlling immigration and immigrant crime through internal controls.

The analyses are based on a data set containing all irregular immigrants who were apprehended by all relevant authorities in the Netherlands between January 1997 and October 2003. This period was taken because 1997 is the first year and 2003 the most recent year for which national police data have been made available for scientific research so far. As described above, measures of internal border control were partly introduced in this period, or in the years just before it. Additionally, these data were combined with administrative data on all non-citizens who have lost their residence permit because of crimes. Finally, the data were compared to police figures on crime suspects with legal status.

The following section discusses the five central explanations of the present study. After introducing the data sources and research methods, the findings will be presented. The concluding section elaborates on the study's theoretical and policy implications.

\section{Five possible explanations of the rise in crime}

The marginalisation thesis

Irregular migration and crime are often conflated in popular imagination [29, 46]. On the whole, it can nonetheless be hypothesised that the involvement of irregular immigrants in crime is actually inhibited by their precarious societal position, in which detention and deportation are inherent risks. Particularly the findings of the early Dutch studies on irregular residence and crime supported this 'deterrence thesis': most irregular immigrants were found to refrain from criminal activities, and the involvement of irregular immigrants in expressive crimes, such as violence and vandalism, was found to be limited [37].

At the same time, there are indications that the crimes irregular immigrants commit are often a response to a marginal social position. The marginalisation thesis is based on empirical findings in a series of studies conducted in the Netherlands, briefly described below. 
First, substantial differences in criminal involvement were found across ethnic groups. In the early $1990 \mathrm{~s} 4 \%$ of irregular Turkish immigrants had come into contact with the Rotterdam police because of criminal activity. For Eastern Europeans, Algerians and Moroccans these percentages were 32, 54 and 65, respectively [22]. On the basis of qualitative fieldwork, this variation was attributed to ethnic differences in social ties and social capital. Many irregular immigrants from Turkey were supported by well-established Turks who moderated the consequences of internal border control by increasing access to formal institutions in informal ways, for instance by sharing health insurance cards, as well as to informal institutions, for instance by arranging informal employment in shops owned by co-nationals. To a large extent, the irregular migration of Turks had the characteristics of organised chain migration; many newcomers knew beforehand where they were going to reside and for whom they would work [53]. Irregular immigrants who were involved in crime had more often migrated to the Netherlands in improvised ways, and received less support from established countrymen. Sometimes resourceful communities were lacking, sometimes ethnic solidarity was weak. These findings were corroborated in in-depth interviews with 165 irregular immigrants in Rotterdam. Respondents with families and permanent residence in the Netherlands reported involvement in crime less frequently than irregular immigrants who lacked kin in the Netherlands and were often travelling from one address to the other [12].

In addition, in a comprehensive study on asylum migration and crime [20] it was found that the relative number of crime suspects among failed asylum seekers residing illegally in the Netherlands was several percent points higher than among officially recognised asylum seekers and asylum seekers still awaiting the conclusion of the procedure. And repeated in-depth interviews with 26 rejected asylum seekers who had become irregular immigrants and were detained in the Aliens Custody for crimes [37] showed that most men in this study had committed subsistence crime in order to meet various social standards that they could not, or believed they could not, realise in conventional ways. Finally, there is the observed rise in documented crime among irregular immigrants, which was mentioned in the introduction. In sum, there are indications that deterrence as a consequence of fear for expulsion may increasingly have been outweighed by marginalisation effects. Suggestive evidence for the notion that irregular residence status depresses criminal involvement unless marginalisation reaches a certain threshold can also be found in the scarce studies on irregular residence and crime that have been conducted in other countries (for the United States see for instance [29, 45] for Germany [2], for Belgium [62], for Italy [44]). Alternative explanations are addressed in the next section.

\section{Reclassification and redefinition}

The first alternative explanation takes the rise in registered crime as the outcome of changes in the way the Dutch state classifies certain migrants as 'irregular immigrants', or changes in the official definition of what constitutes 'crime'.

Whereas the marginalisation thesis argues that irregular status may lead to crime involvement, the opposite can also be true: criminal involvement may lead to an irregular status. Legal immigrants can lose their legal status in case of crime, for instance when they are declared 'undesirable aliens'. In the Netherlands this may be 
done when a non-citizen has committed a crime for which three or more years of imprisonment can be inflicted. Continued residence in the Netherlands then becomes irregular and punishable as a crime for a period of up to 10 years. A residence permit may be also be withdrawn or refused, without the immigrant being declared an undesirable alien in case of deportable crimes that are somewhat less serious, or if a convict's family is living in the Netherlands. ${ }^{4}$ The term 'status reclassification' will be used here for all forms of losing legal status due to criminal activities.

Status reclassification may increase the number of crime suspects with irregular residence status in two main ways. Firstly, such migrants may re-enter or remain in the country. If undesirable aliens are arrested they contribute, per definition, to the total number of crime suspects with irregular residence status. Secondly, it can be expected that additional offending will be relatively common among legal immigrants who have lost their legal status because of crimes. Past offending is the best known predictor of future offending [27].

Over time, status reclassification has become more common in the Netherlands: between 1997 and 2003 the annual prevalence of status reclassification involving non-EU citizens almost doubled from 769 to 1,555 cases. In these 7 years 5,580 nonEU citizens were declared undesirable aliens. One reason for this increase was the introduction of legislation in 2002 that has made it easier for the Dutch state to terminate the legal stay of non-citizens who have been convicted of certain crimes. The most important change is that legally residing migrants now run the risk of losing their residence permit for less serious crimes, at least in the case of short residence durations, i.e. up to 5 years. Additionally, the government has made increased use of the existing legal possibilities to end residence rights of criminal non-citizens. These developments in status reclassification are in line with Stumpf's observations about the merging of criminal law and immigration law: rather than being rehabilitated and re-integrated in Dutch society, non-citizen criminals are increasingly excluded, both socially and territorially, with the help of immigration law [54, 58].

Yet definitional changes with regards to what counts as 'criminal' cannot be a major explanation for the rise in the number of crime suspects under study. It was already in 1994, thus before the research period (1997-2003), that the Netherlands introduced its Identification Act. This Act, which was expanded in 2005, stipulates that every person in the Netherlands has to be able to prove his or her identity with an officially recognised identity document, at least when working, when suspected of a criminal offence, and in case of a 'concrete indication' of illegal residence (in 2001 the latter stipulation was changed to 'reasonable suspicion'). Showing a false document in case of ID checks became punishable as a felony. Not being able to show IDbeing 'sans papiers' in stricto sensu-became punishable as a common misdemeanour. Moreover, at EU level, the 2002 Directive on illegal entry, transit or residence criminalised assistance to irregular migrants to enter or-if assistance occurs for financial gain-to reside in EU member states [64]. This resulted in changes to the

\footnotetext{
${ }^{4}$ According to Article 8 of the European Convention on Human Rights migrants legally residing in a country have a right to maintain a family life there, which conflicts with the implications of a being an undesirable alien. Migrants who lose their residence permit may still bring short visits to the Netherlands, but continued settlement is regarded illegal residence.
} 
Dutch Criminal Law, but these pertained to those offering assistance to irregular migrants rather than to the migrants themselves.

Criminal migration and cross-border crime

The second alternative explanation attributes the rise in crime to changes in criminal migration and cross-border crime. Migrants may decide to cross borders in order to smuggle irregular goods, to seize criminal opportunities in the country of destination, or to escape criminal prosecution. Also, migrants with no further criminal intentions after settlement may use false documents to cross the border in response to external border controls [34]. In the literature the terms criminal migration and cross-border crime are often used to denote such phenomena. Although there are substantial differences among these forms of crime, they can all be contrasted with the marginalisation thesis: in these cases offending is intended beforehand and is not a response to internal border control.

Criminal migration and cross-border crime are under-researched in relation to irregular residence, but their prevalence may have increased in the Netherlands between 1997 and 2003, albeit for different reasons. On the one hand, it is likely that the use of false documents upon entry has become increasingly common, particularly among irregular immigrants who lack social ties in the European Union and have fewer opportunities to overstay tourist visas [37]. Since the 1980s the list of countries requiring a visa to enter the EU has been expanded ([7] see also [26]). On the other hand, external border controls with respect to Eastern Europeans were eased considerably after the fall of the Iron curtain and the European Union's Eastern enlargement. Visa requirements for short visits were already dropped for a number of countries such as Poland in the early 1990s. In 2001 this was done for the, at the time, future EU member states Bulgaria and Romania. It appears that the relaxation of external border controls for Eastern Europeans has facilitated an increase in 'transnational brigandage', in which Eastern European criminals increasingly started committing crimes in Western Europe, such as house burglary and car theft $[10,65]$. Among them were irregular immigrants [68].

\section{Policing}

The third alternative explanation emphasises improved crime detection and crime recording by the Dutch police. The rise in crime among irregular immigrants may simply reflect a general trend in criminal law enforcement and registration. Between 1999 and 2002 the police forces were expanded considerably, from 40,000 to 47,000 policemen [48, page127]. The Dutch police have also become more active in recording crimes in these years [69]. Another possibility is that the police have paid more attention to immigrant crime between 1997 and 2003: police apprehensions are often suspected to be selective with respect to migrants [66]. So far, in the Netherlands, little evidence has been mustered for the proposition that the police differentially arrest by 'foreign appearance' $[8,51]$. It must be noted, however, that recent research is lacking.

An additional possibility is that the police have been giving a higher priority to detecting and/or the recording of offending by irregular immigrants. In order to 
explain this possibility it is helpful to briefly describe how the policing of irregular migrants is organised and carried out in the Netherlands.

The Netherlands has a decentralised police organisation. Apart from a relatively small national police force (FTE was about 4,000 in 2003) and a Military Police force (FTE 6,000), there are 25 local police forces (FTE: 50,000). Each local police force has its own Aliens Police department, responsible for maintaining immigration law. Through the years the regular police conduct about $55 \%$ of the apprehensions during regular policing activities. The Aliens Police are responsible for about a quarter of the apprehensions, which mostly take place during work site checks, or checks on (the residential addresses of) migrants who are suspected of having overstayed their visas. About a fifth is done by the Military Police, who are responsible for external border control (illegal entry, drug trafficking and so forth).

Irregular migrants who are not involved in crimes are underrepresented in Dutch police data. This is partly due to legal stipulations that limit the possibilities for the police to stop persons just to check their residence status: as mentioned in the section on status reclassification and redefinition, the police must have a 'concrete indication' (since 2001: 'reasonable suspicion') of illegal residence to ask for ID. However, policemen's own pragmatic and moral considerations are probably more important than legal stipulations. In 1996 and 1997, we interviewed 170 irregular migrants and 41 police officers working for the Police and the Aliens Departments in the cities of Amsterdam, Rotterdam, The Hague and Utrecht, and found that the police officers considered illegal residence a relatively minor infraction, certainly in comparison to other public safety concerns. [57] Many policemen also recognised that a tougher 'fight against illegality' would probably reduce the willingness on the part of the residents-both unauthorised residents and a larger group of legal migrants in which the former migrants are embedded-to cooperate with the police, for example by reporting crime. We encountered some policemen who had developed a special interest in the tracing of irregular migrants: if such officers observe that persons with a foreign appearance commit certain minor misdemeanours-of the type that are often ignored by the police in many Dutch cities, such as bicycle riders riding without lights or neglecting traffic lights-they may stop the person just to have a legal pretext to ask for ID (in the Netherlands, the checking of residence status can be done on the beat: all regular police have access to a national database in which the immigration status of non-citizens is registered). In most cases, however, we found that the police did not pay much attention to irregular migrants who did not cause trouble in the neighbourhood, targeting crime suspects instead (especially suspects of felonies rather than minor misdemeanours), regardless of residence status. They usually do not know in advance whether a crime suspect resides in the country legally or not, which limits the possibilities for selective policing with respect to legal status.

Field research in later years allowed us to get an impression of any changes in apprehension practices and priorities. In 2000 we interviewed 156 irregular immigrants, and in 2003 and 2004 we again interviewed 65 irregular immigrants, as well as 45 landlords and 20 professionals (of whom 8 policemen). We found that two main developments were taking place that may have increased the number of crime suspects with irregular status. First, there were more efforts to detect identity fraud. For example, the number of work site checks rose, which will have led to a larger number of apprehensions for administrative reasons ('illegal labour') as well as for 
false documents, as workers are asked to show their ID. Likewise, the Military Police had begun to deploy more personnel to trace false documents at the border. Second, the police had to some extent started to specifically target groups of criminal irregular immigrants. In particular in the Amsterdam area, specialised teams have been formed since 2002 to arrest irregular immigrants who are believed to be heavily involved in criminal activities. In the period under study, these teams apprehended approximately 400 (allegedly) criminal irregular immigrants. It has to be noted, however, that not every apprehension that occurs as a result of increased selectivity will lead to a higher number of crime suspects. The Amsterdam teams enter apartments or buildings where groups of criminal migrants are believed to be present, and may not have sufficient evidence to officially suspect and prosecute the arrestees because of crimes. In some cases it is easier to register the apprehension under immigration law and deport the arrestees on administrative grounds.

\section{Demographic changes}

Finally, the rise in the number of crime suspects could simply be a side-effect of developments in the composition of the irregular population, or its size. For instance, involvement in crime correlates with sex and age. It could be that the share of young males has grown between 1997 and 2003, or that the number of crime suspects merely increased proportionally to the size of the irregular population as a whole.

In order to put the marginalisation thesis to a critical test, the alternative explanations were operationalised in ways that put the marginalisation thesis at a disadvantage rather than favouring its corroboration. The data and analytical strategy are described in more detail in the next section.

\section{Data sources, analytical strategy and validity}

\section{Data sources}

The data on apprehended irregular immigrants have been provided by the Dutch police forces and are taken from the national VAS database in which all known irregular immigrants are documented. Entries include information on nationality, sex, age, arrival date in the Netherlands, date of apprehension, and the most serious reason for apprehension. Between January 1997 and October 2003 107,322 apprehensions were registered. Of these, 93,030 concerned irregular immigrants from non-EU countries. This figure includes nationals of countries that have become EU member states after 2003.

As mentioned earlier, most irregular immigrants in the database are apprehended by the regular police. They are either suspected of crime or common misdemeanours (such as ignoring traffic lights) or fall into the hands of the police as 'additional catch', for instance when people are asked to show ID during policing activities. Some irregular immigrants, for instance rejected asylum seekers, have resided legally in the Netherlands before becoming irregular immigrants. They have to report to the Aliens Police on a regular basis and may eventually be apprehended and expelled. Others are apprehended by or handed over to the Aliens Police after border controls, workplace checks or housing inspections in disadvantaged urban areas. 
Almost $70 \%$ of the apprehensions concern males between 20 and 40 years of age, and they come from countries all over the world. The largest groups come from wellknown source countries for immigration to the Netherlands such as Turkey, Morocco and Surinam as well as Eastern European countries (for more details on the composition of the irregular population in the Netherlands see [41, 59]). Approximately $15 \%$ are rejected asylum seekers, mostly from Sub-Saharan Africa, the Middle East and Central Asia.

The Dutch Immigration and Nationalisation Service (IND), a special branch of the Ministry of Justice, provided us with information on status reclassification. They listed all persons who have been declared undesirable aliens and/or who lost a residence permit because of crimes during the period 1997-2003. On the basis of this data all crime suspects could be identified in the VAS data who may have been reclassified legal migrants (this was done using the unique 'foreigner numbers', an administrative number for foreigners, which is included in both the VAS and IND data).

In order to test the policing explanation, statistics on documented crime suspects among Dutch citizens and legally residing migrants were used. The demographic explanation was examined with the help of Cruyff and Van der Heijden's [18] estimations of the size of the undocumented population, for a discussion see [56].

\section{Analytical strategy}

Irregular immigrants can be apprehended for the following reasons: (1) administrative infringements of the Aliens Act-such as irregular residence or working without a working permit-which are not or only mildly punishable; (2) common misdemeanours that are usually punished with a fine, such as fare dodging, driving under the influence of alcohol, and the like; (3) felonies such as shoplifting, car and house burglary, vandalism, staying in the country while being an undesirable alien, robbery, physical assault and several crimes mentioned in the Opium Law, which range from large-scale drug trafficking to petty dealing or drug possession. This article focuses on the third category, which represents about one third (36\%) of the apprehensions; administrative infringements and common misdemeanours are generally not regarded as 'criminal activities' in Dutch society.

The apprehensions for felonies were broken down into four types of crime: 'property crimes', 'false documents', 'drugs', and 'other crimes'. 5 The latter category mainly consists of violence against persons and goods and being in the Netherlands as an undesirable alien. This categorisation in four types of crime was chosen because previous research suggested that offending in response to marginalisation usually concerns subsistence crime and crimes to finance drug use. These are usually property crimes, possession of false papers (working in the formal economy with somebody else's papers), and drug possession and trafficking. On the basis of the theoretical framework a rise in crime with respect to these three types of crime is

\footnotetext{
$\overline{5}$ The category 'property crimes' is taken as an indicator for subsistence crime and addiction-related crime and is defined in a broad sense; it includes some property crimes with a violent component. It entails: 'theft', 'theft with burglary', 'theft with violence', 'conning', 'extortion', 'receiving', 'counterfeiting', and 'embezzlement'. Theft and theft with burglary make up the large majority of the cases in this category (about $80 \%$ ).
} 
expected when the alternative explanations are controlled for, and not so much with respect the category 'other crimes'.

For every year since 1997-the first year for which reliable digital data were available - the number of suspects for each of the four types of crime were totalled. The analyses were also done at the apprehension level, yielding similar results, which will not be presented here. The analyses were limited to migrants from countries that were, at the time, non-EU countries, including Poland (EU member since 2004) and Bulgaria (EU member since 2007). The data for the first three quarters of 2003 were extrapolated to the year as a whole by multiplying all 2003 figures with 12/9.

The methods to control for the alternative explanations are straightforward. When controlling for reclassification and criminal migration, all crime suspects with indications for status reclassification or criminal migration were excluded successively from the annual totals. The policing explanation was examined by comparing the trends on crime suspects with irregular residence status to the general trends in documented crime in the Netherlands. The demographic thesis was examined by comparing the developments in the number of crime suspects with irregular residence status to the (estimated) size and composition of the irregular population as a whole. Operationalisations are dealt with below.

Our indicator for status reclassification is the sum of all crime suspects in the VAS in the period 1997-2003 concerning persons (1) who have been declared undesirable aliens in these years, (2) who applied in vain for a residence permit and/or lost this permit in the period examined due to criminal activities, without being declared undesirable aliens, or (3) who have been apprehended as undesirable aliens in these years but were not declared undesirable aliens in this period (but apparently earlier).

In about $55 \%$ of the apprehended irregular immigrants the police registered an arrival date in the Netherlands. For persons who initially stayed legally in the Netherlands the arrival date is often known because of previous contacts with the authorities. For persons who are have been apprehended more than once as 'irregular aliens', the first apprehension date is often registered as the arrival date. In other instances the police rely on statements by the arrestee about the arrival date if these are deemed sufficiently reliable. A suspect was classified under criminal migration or cross-border crime, if (s)he committed at least one felony within 3 months after arrival in the Netherlands. The underlying assumption is that this type of offending takes place soon after arrival, while offending in response to marginalisation tends to develop more gradually. This too is a fairly broad operationalisation. Different time periods were experimented with, varying from 1 month to 6 months, which yielded substantively similar results.

\section{Validity}

Irregular immigration is an inherently difficult subject for empirical research (Cornelius, 1982). Over the years it has become clear that quantitative data sources can yield valuable results, particularly of the findings are supplemented with qualitative field research, as has been done in Dutch research since the 1990s. The VAS data used in the present article already provided valuable insights on the criminal involvement among irregular immigrants $[24,37,38,57]$ and on the spatial distribution of irregular residence in the Netherlands $[25,40]$.

It has often been argued that police data are problematic for scientific purposes. There is, for instance, a substantial quantity of crime that never shows up in police 
files. This 'dark number' can be reduced by using self-report studies, but for irregular immigrants this is unrealistic. Two main sources of bias are relevant here. First, attention of law enforcers commonly concentrates on strategic sites, such as train stations or crime-ridden areas, as well as on lower-status neighbourhoods. As irregular immigrants tend to be concentrated in deprived urban neighbourhoods with elevated crime rates [38], they may have a higher likelihood to be stopped by the police if they engage in crime there. The second source of bias pertains to the possible selectivity of police data with respect to racial minorities and immigrants.

Both biases may inflate the representation of irregular immigrants in documented crime in comparison with native and higher status groups. Fortunately, the implications of these biases were limited in this study. The development over time in the number of crime suspects within the irregular population is of primary interest here. Moreover, it could be examined whether the police have become increasingly selective towards immigrants-regardless of legal status-by comparing the trend data on irregular immigrants with police data on legal immigrants with similar national backgrounds.

In sum, police data have their drawbacks, but are nonetheless an important data source to study patterns of criminal activity among irregular immigrants, in particular when problems of selectivity and bias are taken into account as is attempted here [55].

\section{Testing the alternative explanations}

Table 1 starts with an overview of crime suspects. In 1997 the police registered 3,170 crime suspects with irregular status. In 2003 this figure had more than doubled to 7,337 (2003 index: 231). The table also includes figures on suspect rates, i.e. the percentage of the population that is registered as a suspect annually. This is done for irregular immigrants and for comparable immigrants with legal status. To calculate irregular immigrants' suspect rate Cruyff and Van der Heijden's estimates of the total irregular population were used [18]. Note that during the 1990s the suspect rate among irregular immigrants was considerably lower than among legal non-Western immigrants, which confirms the deterrence thesis. In later years, however, it increasingly equals the suspect rate among legal migrants, particularly when compared to the first generation.

\section{Reclassification}

It turns out that a substantial number of reclassified immigrants are among the irregular immigrants apprehended from crimes: they represent about 3,300 crime suspects in the VAS data. ${ }^{6}$ Thus, in order to control for the effects of status reclassification all cases involving 'reclassified' suspects were subtracted from the annual totals (Table 2, Control 1). In doing so, it is found that the increase in status reclassification explains about $6 \%$ of the rise in registered crime: whereas for all cases the crime index in 2003 was 231 (Table 1), it is 223 when only the nonreclassified cases are taken into consideration $((231-223) * 100 /(231-100) \approx 6 \%)$.

\footnotetext{
${ }^{6}$ It appears that about one third of these pertain to status reclassification before 1997: these suspects were apprehended as an undesirable alien between 1997 and 2003, but were not reclassified in these years.
} 


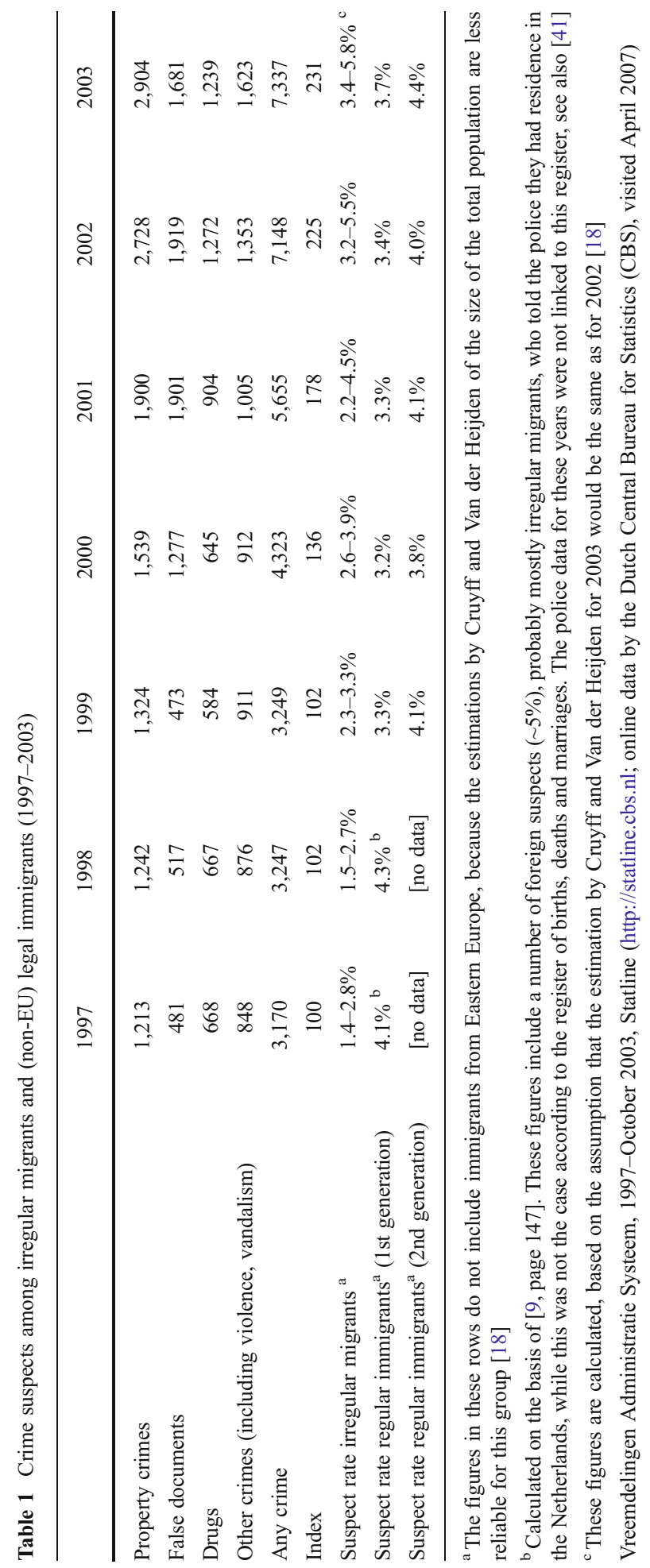


Table 2 Crime suspects among irregular (non-EU) migrants controlling for alternative hypotheses (1997-2003)

\begin{tabular}{|c|c|c|c|c|c|c|c|}
\hline & 1997 & 1998 & 1999 & 2000 & 2001 & 2002 & 2003 \\
\hline \multicolumn{8}{|c|}{ After control 1 (reclassification) } \\
\hline Property crimes & 1,168 & 1,184 & 1,267 & 1,454 & 1,798 & 2,537 & 2,765 \\
\hline False documents & 481 & 515 & 471 & 1,275 & 1,892 & 1,909 & 1,677 \\
\hline Drugs & 658 & 650 & 528 & 478 & 629 & 1,022 & 1,171 \\
\hline Other crimes & 796 & 811 & 817 & 801 & 823 & 1,058 & 1,295 \\
\hline Any crime & 3,069 & 3,115 & 3,048 & 3,970 & 5,098 & 6,443 & 6,840 \\
\hline Index & 100 & 101 & 99 & 129 & 166 & 210 & 223 \\
\hline \multicolumn{8}{|c|}{ After control 2 (criminal migration and cross-border crime) } \\
\hline Property crimes & 936 & 925 & 939 & 1,043 & 1,220 & 1,817 & 2,069 \\
\hline False documents & 311 & 358 & 204 & 495 & 688 & 841 & 715 \\
\hline Drugs & 296 & 339 & 312 & 333 & 320 & 457 & 567 \\
\hline Other crimes & 734 & 708 & 732 & 668 & 612 & 839 & 1,055 \\
\hline Any crime & 2,246 & 2,289 & 2,157 & 2,508 & 2,808 & 3,880 & 4,352 \\
\hline Index & 100 & 102 & 96 & 112 & 125 & 173 & 194 \\
\hline \multicolumn{8}{|c|}{ After control 3 (policing) } \\
\hline Property crimes & 936 & 925 & 930 & 1,033 & 1,162 & 1,594 & 1,669 \\
\hline False documents & 311 & 358 & 202 & 490 & 655 & 738 & 577 \\
\hline Drugs & 296 & 339 & 309 & 330 & 305 & 401 & 457 \\
\hline Other crimes & 734 & 708 & 725 & 661 & 583 & 736 & 851 \\
\hline Any crime & 2,246 & 2,289 & 2,136 & 2,483 & 2,674 & 3,404 & 3,510 \\
\hline Index & 100 & 102 & 95 & 111 & 119 & 152 & 156 \\
\hline \multicolumn{8}{|c|}{ After control 4 (demographic developments) } \\
\hline Property crimes & 936 & 974 & 1,257 & 1,215 & 1,107 & 1,398 & 1,464 \\
\hline False documents & 311 & 377 & 273 & 576 & 624 & 647 & 506 \\
\hline Drugs & 296 & 357 & 418 & 388 & 290 & 352 & 401 \\
\hline Other crimes & 734 & 745 & 980 & 778 & 555 & 646 & 746 \\
\hline Any crime & 2,246 & 2,409 & 2,886 & 2,921 & 2,547 & 2,986 & 3,079 \\
\hline Index & 100 & 107 & 128 & 130 & 113 & 133 & 137 \\
\hline
\end{tabular}

\footnotetext{
${ }^{a}$ Extrapolated figures on the basis of data until October 1 st

$\mathrm{b}$ These figures are calculated, based on the assumption that Cruyff and Van der Heijden's estimation for 2003 would be the same as for 2002

Vreemdelingen Administratie Systeem, 1997-October 2003; Immigration and Naturalisation Service Data (IND); CBS Statline (http://statline.cbs.nl; online data by the Dutch Central Bureau for Statistics (CBS) visited April 2007)
}

\section{Criminal migration and cross-border crime}

In the period $1997 / 200337 \%$ of all irregular immigrants apprehended for crimes were suspected of committing at least one crime within 3 months of arrival (Table 3). This percentage is probably an overestimation of the actual share of criminal migration and cross-border crime in the Netherlands: the date of arrival is 
Table 3 Crime suspects without legal status (non-EU), apprehended before 3 months after arrival, $1997-2003^{\mathrm{a}}$

\begin{tabular}{|c|c|c|c|c|c|c|c|c|c|c|c|c|c|c|}
\hline & \multicolumn{2}{|c|}{$\begin{array}{l}\text { Aggravated } \\
\text { property } \\
\text { crimes }\end{array}$} & \multicolumn{2}{|c|}{$\begin{array}{l}\text { Other } \\
\text { property } \\
\text { crimes }\end{array}$} & \multicolumn{2}{|c|}{$\begin{array}{l}\text { False } \\
\text { documents }\end{array}$} & \multicolumn{2}{|c|}{$\begin{array}{l}\text { Drug- } \\
\text { trafficking }\end{array}$} & \multicolumn{2}{|l|}{$\begin{array}{l}\text { Drugs } \\
\text { other }\end{array}$} & \multicolumn{2}{|l|}{$\begin{array}{l}\text { Other } \\
\text { crimes }\end{array}$} & \multicolumn{2}{|l|}{$\begin{array}{l}\text { Any } \\
\text { crime }\end{array}$} \\
\hline & $\mathrm{N}$ & $\%^{b}$ & $\mathrm{~N}$ & $\%^{b}$ & $\mathrm{~N}$ & $\%^{b}$ & $\mathrm{~N}$ & $\%^{b}$ & $\mathrm{~N}$ & $\%^{b}$ & $\mathrm{~N}$ & $\%^{b}$ & $\mathrm{~N}$ & $\%^{b}$ \\
\hline 1997 & 136 & 20 & 98 & 17 & 170 & 35 & 16 & 50 & 346 & 54 & 77 & 9 & 840 & 26 \\
\hline 1998 & 151 & 23 & 112 & 19 & 157 & 30 & 19 & 33 & 295 & 48 & 111 & 13 & 840 & 26 \\
\hline 1999 & 180 & 26 & 163 & 24 & 269 & 57 & 22 & 48 & 224 & 42 & 99 & 11 & 943 & 29 \\
\hline 2000 & 220 & 30 & 210 & 25 & 780 & 61 & 6 & 55 & 252 & 40 & 153 & 17 & 1,609 & 37 \\
\hline 2001 & 338 & 35 & 267 & 28 & 1,209 & 64 & 30 & 58 & 498 & 58 & 256 & 25 & 2,578 & 46 \\
\hline 2002 & 437 & 31 & 332 & 24 & 1,069 & 56 & 504 & 90 & 238 & 33 & 267 & 20 & 2,816 & 39 \\
\hline $2003^{b}$ & 373 & 26 & 339 & 22 & 964 & 57 & 376 & 85 & 257 & 32 & 272 & 17 & 2,555 & 35 \\
\hline $\begin{array}{l}\text { 1997-2003 } \\
\text { of which: }\end{array}$ & 1,717 & 29 & 1,436 & 24 & 4,600 & 56 & 973 & 81 & 2,054 & 45 & 1,213 & 17 & 11,844 & 37 \\
\hline $\begin{array}{l}\text { Europe } \\
\text { (non-EU) }\end{array}$ & 1,358 & 40 & 990 & 32 & 1,342 & 56 & 75 & 75 & 303 & 26 & 520 & 26 & 4,616 & 40 \\
\hline Africa & 189 & 12 & 263 & 14 & 1,654 & 53 & 273 & 74 & 679 & 33 & 386 & 13 & 3,333 & 30 \\
\hline $\begin{array}{c}\text { Asia (incl. } \\
\text { Turkey) }\end{array}$ & 81 & 17 & 126 & 19 & 1,099 & 57 & 70 & 87 & 224 & 40 & 223 & 15 & 1,802 & 36 \\
\hline $\begin{array}{l}\text { Latin- } \\
\text { America }\end{array}$ & 60 & 16 & 48 & 12 & 493 & 67 & 524 & 85 & 778 & 64 & 61 & 12 & 1,943 & 52 \\
\hline $\begin{array}{l}\text { Other non-EU } \\
\text { countries }\end{array}$ & 2 & 7 & 9 & 19 & - & - & 31 & 100 & 70 & 74 & 23 & 30 & 146 & 49 \\
\hline
\end{tabular}

${ }^{a}$ Figures for 2003 were extrapolated on the basis of data until October 1st

${ }^{\mathrm{b}}$ The cells in these columns indicate which percentage of the suspects of this crime type have been suspected of committing at least one crime within 3 months of stay (not necessarily the same crime or type of crime)

Vreemdelingen Administratie Systeem, 1997-October 2003

more likely to be registered in case of an apprehension at the border than in case of an apprehensions within the country after irregular settlement has taken place (a registered arrival date is necessary in order to calculate the duration of stay).

The proportion of criminal migration and cross-border crime differs per type of crime as specified in Table 3. Three types of crimes stand out: drug-trafficking, false documents, and aggravated property crimes. Of all suspects of drug trafficking $81 \%$ have been suspected of committing a crime (drug-trafficking or any other type of crime) within 3 months of arrival. For false documents this percentage is 56 . The share of criminal migration and cross-border crime is also somewhat elevated among property crimes with burglary or violence, particularly among Eastern Europeans (40\%).

To what extent do criminal migration and cross-border crime explain the rise in the number of crime suspects with irregular status? This was researched by subtracting all crime suspects who have been suspected of committing a crime before 3 months of stay from the annual totals that have remained after control 1. As a result, the crime index for 2003 dropped further from 223 to 194 (Table 2), suggesting that criminal 
migration and cross-border crime may explain about $22 \%$ of the total increase ((223$194) * 100 /(231-100)=22 \%$ ). It should be noted that part of this $22 \%$ probably reflects increased policing of false documents at the border.

\section{Policing}

According to Statistics Netherlands, the number of crime suspects increased with $24 \%$ in the legal population (citizens and legal non-citizens) between 1997 and 2003. ${ }^{7}$ Between 1997 and 2003 the Dutch population grew by approximately 5\%. Thus, it is not unlikely that the number of criminals may actually have increased in the legal population. Yet, in order to subject the marginalisation thesis to a critical test it was assumed that the increase in the number of crime suspects with legal status has only been caused by changes in policing. Therefore, the crime indexes for irregular immigrants were recalculated so that possible general developments in policing are kept constant. This was done by dividing the relative number of irregular crime suspects for a given year by the relative number of legal crime suspects for that year compared to 1997. In other words, the number of suspects in 1997 who remained after control 2 was divided by one, the number of suspects in 2001 by 1.05 (between 1997 and 2001 the number of suspects increased with 5\%), the number of suspects for 2003 by 1.24 , and so on.

As a result of this third control, the 2003 crime index for irregular immigrants dropped further from 196 to 156 . Thus, although general developments in policing may account for a significant part of the rise in registered crime among irregular immigrants (about 29\%) the rise in the number of 'illegal' crime suspects is still considerably steeper than in the legal population.

It is possible that the police have paid more attention to ethnic minorities and immigrants between 1997 and 2003. Yet, this is not confirmed by the data that have already been presented in Table 1. If there would have been a question of increased selectivity towards ethnic minorities a rise in the suspect rate among immigrants would be expected, regardless of legal status. This is, however, not the case: the suspect rate among legal migrants has not increased between 1997 and 2003.

Finally, the police may have deployed more resources over time to trace identity fraud by irregular immigrants and to target criminal irregular immigrants, for instance in Amsterdam. To control for this all known cases concerning false documents were excluded-not just the cases that were already excluded in the second control. Due to this additional control, the crime index for 2003 only dropped marginally from 156 to 154 (figures not in table). When the apprehensions in Amsterdam were excluded in addition, the crime index for 2003 actually increased somewhat.

It should be reported that the number of crime suspects with illegal status also increased in comparison to the number of irregular migrants apprehended for illegal residence, illegal labour, and common misdemeanours (this was already mentioned in the introduction). This is an additional indication that the rise in crime does not merely reflect a tendency to apprehend more irregular migrants.

\footnotetext{
${ }^{7}$ Source: CBS Statline (http://statline.cbs.nl, visited April 2007).
} 
In conclusion, the rise in crime under study does not appear to be due to changes in how the police dealt with immigrants in general and irregular immigrants in particular-apart from increased tracing of false documents at the border-but $29 \%$ may be linked with general changes in policing in the Netherlands.

\section{Demographic changes}

Finally, the rise in the number of crime suspects may have been caused by changes in the composition of the irregular population, or its size.

Some idea about the possible impact of the composition of the irregular population can be obtained by looking at the demographic characteristics of all apprehended irregular immigrants, including migrants who have been apprehended for non-criminal reasons. We find that the rise in crime does not appear to be the result of a steep rise in the number of illegally residing males or youngsters. The share of males increased only marginally from $79 \%$ in 1997 to $81 \%$ in 2003 , and the average age rose from 28.8 to 29.7 in this period. Finally, the rise in the number of crime suspects with irregular status may be related to developments in the size of the irregular population in the Netherlands. Figure 1 shows the development of the estimated size of the irregular population since 1997, using Cruyff and Van der Heijden's

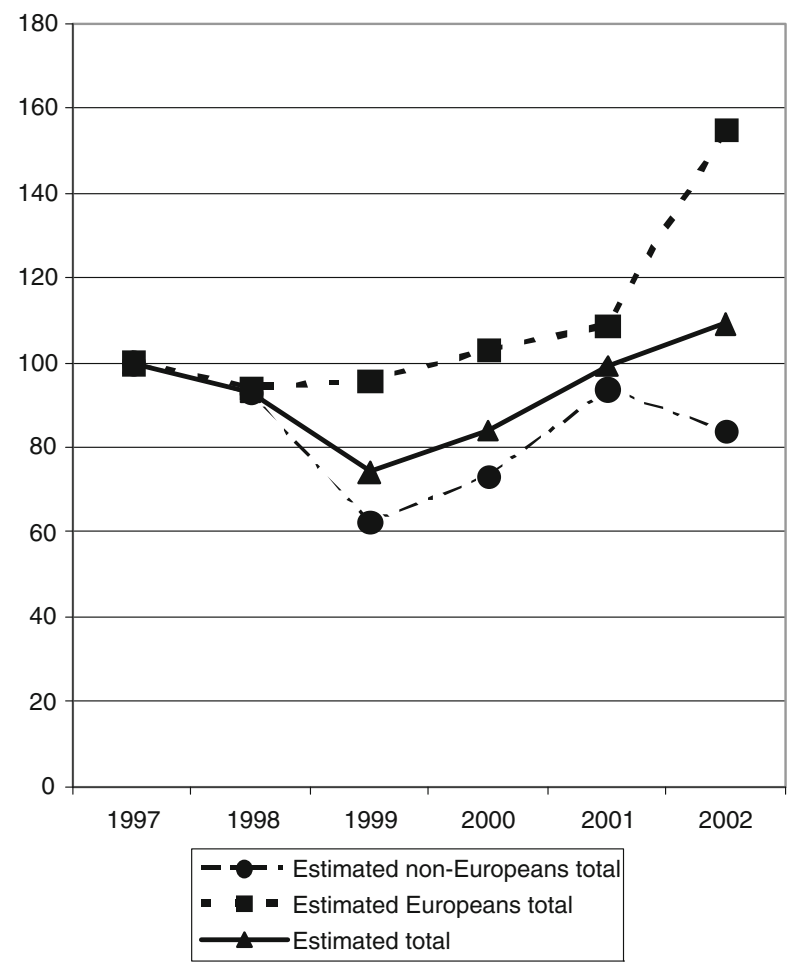

Fig. 1 Relative developments in the estimated undocumented population from Eastern Europe and other non-EU countries. Notes: ${ }^{\text {a }}$ Cruyff and Van der Heijden's estimations of the size of the irregular European population include (a minority) of irregular Western-Europeans who have been declared undesirable aliens. Sources: Vreemdelingen Administratie Systeem, 1997-2002; Estimations taken from [18, pp. 38-39] 
calculations, which include separate estimations for Europeans and non-Europeans [18]. The estimations for 1997 have been set at 100. Whereas the number of nonEuropean irregular immigrants was more or less stable or decreasing somewhat, the estimated number of irregular immigrants from Eastern Europe has increased. After 2001 there may have been a small net increase in the total irregular population, i.e. Europeans and non-Europeans combined. Still, this increase is clearly less substantial than the increase in the number of crime suspects that remained after control 3.

The figures in Table 2 after control 3 were adjusted for the estimated changes in the size of the irregular population in the same way as was done for control 3 . The number of non-European crime suspects for 2002 was, for example, divided by 0.83 , whereas the number of European crime suspects was divided by 1.55 . (The estimations for 2002 were used to adjust the figures for 2003, because no estimation for 2003 was available). ${ }^{8}$ As a result, the suspect rate for 2003 dropped somewhat further from 156 to 137, which is still considerably higher than hundred (Table 2). Note also that the results after control 4 show an increase in property crimes, false documents and drugs-i.e. the indicators for subsistence and drug-related crimes -, but not for the category 'other crimes'. This constitutes additional evidence for the marginalisation thesis.

\section{Conclusion}

In this article the marginalisation thesis - the idea that internal border control of the type that was implemented in the Netherlands may generate crime among those individuals who do not leave the country-was subjected to a critical examination, taking the Netherlands as a test case. It becomes clear that a combination of factors has contributed to the observed rise in crime suspects with irregular status. We find that general developments in policing and police registration may account for $29 \%$ of the increase, whereas criminal migration and cross-border crime account for $22 \%$. Demographic growth (15\%) and status reclassification (6\%) appear to have been less influential. In our analysis, marginalisation effects are responsible for the remaining part, i.e. $28 \%$ of the increase. ${ }^{9}$ This may be taken as a conservative estimate because the alternative explanations were systematically favoured in the analyses over the marginalisation thesis.

The main conclusion is, therefore, that the increase in internal border control by means of excluding irregular immigrants from the formal labour market and public provisions has heightened criminal involvement as an unintended side-effect, predominantly in the form of fostering subsistence crime and drug-related crime.

To make the effects of marginalisation more tangible, it can be calculated that marginalisation as a result of the intensification of internal control in the Netherlands

\footnotetext{
${ }^{8}$ The number of non-European crime suspects for 2002 was, for example, divided by 0.83 , whereas the number of European crime suspects was divided by 1.55. The estimations for 2002 were used to adjust the figures for 2003, because no estimation for 2003 was available.

9 The relative increase between 1997 and 2003 is 131 (231-100). Of this, status reclassification explains 8 (231-223), criminal migration 29 (223-194), general developments in crime finding and registration 38 (194-156), and demographic growth 19 (156-137). These figures are approximations also because the order of the controls influences the outcomes to some extent.
} 
may have led to at least 3,000 additional crime suspects between 1997 and $2003 .{ }^{10}$ For irregular immigrants this development is significant. Their chances of becoming involved in subsistence and/or drug-related crime appear to have increased, on average, by at least $37 \%$ between 1997 and 2003 (this is not the same as $28 \%$ of the increase being explained by marginalisation effects, see note). ${ }^{11}$ Furthermore, the total criminogenic effects of internal border control are probably somewhat stronger, because the alternative explanations were operationalised according to broad criteria and irregular immigrants were already excluded from the formal labour market in the Netherlands in 1991, 6 years before this study's starting point.

Having said that, the increase is limited compared to crime problems in the Netherlands in general. The additional 3,000 crime suspects equal $0.15 \%$ of the suspects in the legal population between 1997 and 2003. Although irregular immigrants appear to have become overrepresented in crime statistics in recent years, their criminal activities still account for a very small part of all crimes committed in the Netherlands.

A theoretical implication of the findings is that in order to understand immigrant crime today, researchers should pay attention to the ways in which states embrace or exclude migrants. Intensified regulation constitutes, more or less by definition, new forms of legality and therefore, by implication, of illegality, such as entering a country without valid papers or not reporting to the aliens police after arrival. Moreover, this article showed that there are complex relations between internal border control and 'conventional' crime such as theft and violence. While the threat of exclusion from the national territory may depress suspect rates via the criminological mechanism of deterrence and social control, exclusion from the labour market and public provisions seems to increase the likelihood of certain criminal responses via the criminological mechanism of strain. The latter type of internal control incites certain criminal responses as it increases the likelihood of migrants being unable to support themselves in conventional ways [1,47]. This is an ideal-typical distinction: internal control of the first type may activate mechanisms that tend to be associated with the second type. For example, traffic checks are a form of internal control of the first type that is increasingly common in some localities in the US, which may foster subsistence crime indirectly if they reduce employment opportunities by reducing commuting opportunities.

Our findings are in line with the tenor of the literature on crimmigration and the securitisation of migration: the expansion of border control brings about a stronger association between illegal residence and crime. We also agree that this association is partly the result of policies and practices of redefinition, reclassification, and policing. However, we have tried to go a step further by showing that constructivist approaches risk missing an important part of the picture: it is not only the discourse, the law and

\footnotetext{
$\overline{10}$ The development in the number of crime suspects after control $4 \mathrm{~b}$ was compared to the hypothetical situation in which the number of such suspects would have remained stable $((\Delta=2,409-2,246)+(2,886-$ $2,246)+(3,079-2,246)=3,352)$.

${ }^{11}$ The increase is $37 \%$ (137 vs. 100) if we assume that all the crime suspects who remain after control $4 \mathrm{~b}$ can be explained under the marginalisation thesis. The increase is higher if these remaining crimes have, in part, other backgrounds that are unconnected to state policies (such as 'honour violence'). For instance the increase is $48 \%$ if in every year 500 crime suspects offended because of such reasons $((3,079-500) /(2,246-$ $500)=1.48)$.
} 
the behaviour of law enforcement agencies that may change, but also the behaviour of migrants.

A second addition is that, from a constructivist perspective, the criminalisation of migrants seems to have been intended by governments, as it performs various positive functions for the state (such as legitimising the introduction of new surveillance techniques, or maintaining popular support in the face of increasing socioeconomic uncertainly). Yet by and large, the rise in crime among irregular migrants in the Netherlands seems to have been an unintended and undesired side-effect of state intervention. For example, there is now a significant group of vulnerable irregular migrants in the Netherlands, composed of people who cannot find sufficient employment and who do not have a family or partner to support them. Many local governments - faced with the results of restrictive immigration policy in the form of homeless and criminal irregular migrants on their streets - continue to subsidise accommodation for certain categories of irregular migrants or even organise accommodation themselves. Moreover, the national government has begun to detain substantial numbers of marginalised irregular migrants in immigration detention, often repeatedly, to manage public safety problems [39].

At the same time, right-wing parties are inclined to use police information and media reports about the increased representation of irregular immigrants in crime statistics to legitimise even more restrictive immigration policies. For example, in 2008 two major right wing parties introduced a resolution to make illegal residence a felony, in which they argued that illegal residence 'will have to be deterred much more effectively because it causes major problems for Dutch society, for example with respect to safety [...]'. The resolution was rejected, but the present centre-right government does intend to make illegal residence punishable as an offence, although it remains to be seen if this is feasible within the European Union. Thus, all in all, what seems to have occurred in the Netherlands is that a discourse in which illegal residence was framed as a socio-economic threat has been replaced by a discourse in which it is portrayed as a threat to public safety.

Although the effects of internal border control were central in this article, the analysis also pointed to unintended repercussions of open external borders. If free movement of legal goods and certain persons is promoted, as is done as part of the project of European integration, it is also easier for criminals to migrate to other countries to commit crimes like drug trafficking or aggravated theft (this does not imply that such phenomena will occur with high frequency, as is sometimes suggested by certain media reports). This is the more likely if there are large economic disparities between the countries involved. In such circumstances, relatively closed and relatively open societies may foster specific forms of immigrant crime.

The findings are highly relevant for policy making in the field of irregular residence. The United States have traditionally focused more on controlling its external physical borders [3, 43], whereas Scandinavian countries, Germany and France, for example, have also put much more emphasis on guarding their labour market and public provisions [17, 19, 21, 27, 30]. In spite of these national differences, there is an apparent tendency in most countries to exclude irregular immigrants from the labour market and public provisions. In 2009, for instance, the European Commission enacted Council Directive 2009/52, which provides for sanctions against employers of illegally staying third country nationals. A recent international 
comparison of Spain, Italy, Greece, Austria, France, Germany, the UK and the Netherlands also led to the conclusion that "controls within these countries have intensified in the last 4-5 years" [15: 125]. The United States has adopted such policies of internal control as well, including stricter law-enforcement. This is done, for example, though the federal program E-Verify, which checks the residence status of workers. Since 2005 in particular, policies of internal border control have also been implemented at the level of individual states. In the past few years, the majority of American states have adopted measures to curb employment and residence by irregular immigrants via more severe employer sanctions, decreased access to ID's, the denial of state contracts to companies working with irregular immigrants, or by excluding irregular immigrants from public benefits [see also [33, 49, 63]]. There are now four states where e-verify is mandatory for all employers, as well as eight states where e-verify is mandatory for state employers and/or contractors. ${ }^{12}$

Research in other countries may provide additional evidence for the mechanisms that were central in this article or find different outcomes in different settings. In countries with a larger informal economy and a larger private housing market, for instance, a shift to informal practices may be more likely than a shift towards crime. Moreover, in federations such as the US it may be relatively easy for irregular immigrants to leave states with strict internal controls, and move to relatively permissive states. But although the Dutch case may be specific in certain respects, it unequivocally points to the need of taking into account the intended and unintended consequences of immigration policies, as well as to the need of paying attention to external and internal border control in the study of immigration and crime.

Open Access This article is distributed under the terms of the Creative Commons Attribution License which permits any use, distribution, and reproduction in any medium, provided the original author(s) and the source are credited.

\section{References}

1. Agnew, R. (1992). Foundation for a general strain theory of crime and delinquency. Criminology, 30, $47-87$.

2. Alt, J. (2003). Leben in der Schattenwelt: Problemkomplex illegale migration. Karlsruhe: von Loeper.

3. Andreas, P., \& Snyder, T. (Eds.). (2000). The wall around the West. State borders and immigration controls in North-America and Europe. Lanham: Rowman \& Littlefield.

4. Angel-Ajani, A. (2003). A question of dangerous races? Punishment \& Society, 5, 433-448.

5. Bigo, D. (2002). Security and immigration: Toward a critique of the governmentality of unease. Alternatives, 27, 63-92.

6. Bigo, D. (2004). 'Criminalisation of migrants': The side effect of the will to control the frontiers and the sovereign illusion. In B. Bogusz, R. Cholewsinski, A. Cygan, \& E. Szyszczak (Eds.), Irregular migration and human rights: Theoretical, European and international perspectives (pp. 61-91). Leiden/Boston: Marinus Nijhof Publishers.

7. Bigo, D., \& Guild, E. (2005). Controlling frontiers: Free movement into and within Europe. Aldershot: Ashgate.

8. Boekhoorn, P., Speller, T., \& Kruijssen, F. (2004). Operationeel toezicht vreemdelingen; evaluatie van de bevoegdheden in de Vreemdelingenwet 2000 voor het vreemdelingentoezicht door de politie. The Hague: Boom Juridische Uitgevers.

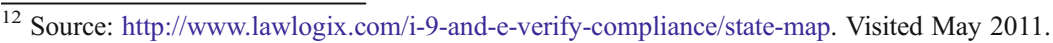


9. Boerman, F., Van Tilburg, W., \& Grapendaal, M. (2003). Landelijke criminaliteitskaart 2000-2001. Aangifte- en verdachtenanalyse op basis van HKS gegevens. Zoetermeer: KLPD (National Police).

10. Bort, E. (2000). Illegal migration and cross-border crime: Challenges at the Eastern frontier of the European Union. San Domenico: European University Institute.

11. Broeders, D., \& Engbersen, G. (2007). The fight against illegal migration. Identification policies and immigrants' counter strategies. American Behavioral Scientist, 50(12), 1592-1609.

12. Burgers, J., \& Engbersen, G. (Eds.). (1999). Illegale Vreemdelingen in Rotterdam. Amsterdam: Boom.

13. Carling, J. (2007). Migration control and migrant fatalities at the Spanish-African borders. International Migration Review, 41, 316-343.

14. Carter, D., \& Merrill, H. (2007). Bordering humanism: Life and death on the margins of Europe. Geopolitics, 12, 248-264.

15. CLANDESTINO. (2009). CLANDESTINO Project. Final report. Athens: Clandestino Project.

16. Cornelius, W. (2001). Death at the border: Efficacy and unintended consequences of US immigration control policy. Population and Development Review, 27, 661-685.

17. Cornelius, W., Tsuda, T., Martin, Ph, \& Hollifield, J. (Eds.). (2004). Controlling immigration: A global perspective. Stanford California: Stanford University Press.

18. Cruyff, M., \& Van der Heijden, P. (2004). Een raming van het aantal illegalen in Nederland. In A. Leerkes, M. van San, G. Engbersen, M. Cruijff, \& P. van der Heijden (Eds.), Wijken voor illegalen: Over ruimtelijke spreiding, huisvesting en leefbaarheid (pp. 31-42). The Hague: Sdu Uitgevers.

19. Cyrus, N., \& Vogel, D. (2003). Work-permit decisions in the German labour administration: An exploration of the implementation process. Journal of Ethnic and Migration Studies, 29, 225-255.

20. De Boom, J., Engbersen, G., \& Leerkes, A. (2006). Asielmigratie en criminaliteit. Apeldoorn: Police and Science.

21. Düvell, F. (Ed.). (2006). Illegal immigration in Europe. Beyond control? Houndsmills: Palgrave MacMillan.

22. Engbersen, G., \& Van der Leun, J. P. (1995). Illegale vreemdelingen en criminaliteit: De differentiële kansenstructuur van illegalen. Tijdschrift voor Criminologie, 37(3), 238-256.

23. Engbersen, G., \& Van der Leun, J. P. (1998). Illegality and criminality. The differential opportunity structure of illegal immigrants. In K. Koser \& H. Lutz (Eds.), The new migration in Europe. Social constructions and social reality (pp. 199-223). London: Macmillan.

24. Engbersen, G., \& Van der Leun, J. P. (2001). The social construction of illegality and criminality. European Journal on Criminal Policy and Research, 9(1), 51-70.

25. Engbersen, G., Van San, M., \& Leerkes, A. (2006). A room with a view. Illegal immigrants in the legal capital of the world. Ethnography, 7, 209-242.

26. Goodey, J. (2003). Migration, crime and victimhood. Responses to sex trafficking in the EU. Punishment \& Society, 5, 415-431.

27. Gottfredson, M., \& Hirschi, T. (1990). A general theory of crime. Stanford California: Stanford University Press.

28. Guiraudon, V., \& Lahav, G. (2007). Immigration policy in Europe. The politics of control. London: Routledge.

29. Hagan, J., \& Palloni, A. (1999). Sociological criminology and the mythology of Hispanic immigration and crime. Social Problems, 46, 617-623.

30. Heckmann, F. (2004). Illegal migration: What can we know and what can we explain? the case of Germany. International Migration Review, 38, 1103-1125.

31. Huysmans, J. (1995). Migrants as a security problem: The dangers of "securitizing" social issues. In R. Miles \& D. Thranhardt (Eds.), Migration and European integration: The dynamics of inclusion and exclusion (pp. 53-72). London: Pinter.

32. Huysmans, J. (2000). The European Union and the securitization of migration. Journal of Common Market Studies, 38(3), 497-518.

33. Jencks, C. (2007). The immigration charade. New York Review of Books, LIV(14), 49-52.

34. Kyle, D., \& Siracusa, C. (2005). Seeing the state like a migrant. Why so many non-criminals break immigration laws. In W. Van Schendel \& I. Abraham (Eds.), Illicit flows and criminal things: States, borders, and the other side of globalization (pp. 153-176). Bloomington: Indiana University Press.

35. Labour Inspectorate. (1999). Jaarverslag 1998. The Hague: Ministry of Social Affairs and Employment.

36. Labour Inspectorate. (2005). Jaarverslag 2004. The Hague: Ministry of Social Affairs and Employment.

37. Leerkes, A. (2009). Illegal residence and public safety in the Netherlands. Amsterdam: Amsterdam University Press. 
38. Leerkes, A., \& Bernasco, W. (2010). The spatial concentration of illegal residence and neighbourhood safety. Journal of Urban Affairs, 32(3), 367-392.

39. Leerkes, A., \& Broeders, D. (2010). A case of mixed motives? formal and informal functions of immigration detention. British Journal of Criminology, 50, 830-850.

40. Leerkes, A., Engbersen, G., \& Van San, M. (2007). Shadow places. Patterns of spatial concentration and incorporation of irregular immigrants in the Netherlands. Urban Studies, 44(8), 1491-1516.

41. Leerkes, A., Van San, M., Engbersen, G., Cruijff, M., \& van der Heijden, P. (2004). Wijken voor illegalen. Over ruimtelijke spreiding, huisvesting en leefbaarheid. The Hague: SdU.

42. Lyon, D. (2005). The border is everywhere: ID cards, surveillance, and the other. In E. Zureik \& M. Salter (Eds.), Global surveillance and policing: Borders, security, identity (pp. 66-82). Cullumpton: Willan Publishing.

43. Mahler, S. (1995). American dreaming: Immigrant life on the margins. Princeton: Princeton University Press.

44. Mastrobuoni, G., \& Pinotti, P. (2011). 'Migration restrictions and criminal behavior: Evidence from a natural experiment', paper presented in London at the Norface Conference on migration.

45. McDonald, W. (1997). Illegal immigration: Crime, ramifications and control (the American experience). In W. McDonald (Ed.), Crime and law enforcement in the global village (pp. 65-86). Cincinnati: Anderson Publishing Company.

46. Melossi, D. (2003). "In a peaceful life": Migration and crime of modernity in Europe/Italy. Punishment \& Society, 5, 371-397.

47. Merton, R. (1938). Social structure and anomie. American Sociological Review, 3, 672-682.

48. Ministry of Justice. (2005). Criminaliteit en rechtshandhaving 2004. Ontwikkelingen en samenhangen. The Hague: WODC.

49. National Conference of State Legislatures (NCSL). (2009). State laws related to immigrants and immigration in 2008. (Revised January 27, 2009). Washington: NCLS.

50. Pluymen, M., \& Minderhoud, P. (2002). Access to public services as an instrument of migration policy in the Netherlands. Tolley's Journal of Immigration, Asylum and Nationality Law, 16(4), 208223.

51. Rovers, B. (1999). Klassenjustitie: Een overzicht van onderzoek naar selectiviteit in de Nederlandse strafrechtsketen. Rotterdam: Erasmus University Rotterdam.

52. Spijkerboer, T. (2007). The human costs of border control. European Journal of Migration and Law, 9 , 147-161.

53. Staring, R. (2001). Reizen onder regie: Het migratieproces van illegale Turken in Nederland. Amsterdam: Het Spinhuis.

54. Stumpf J (2006). The crimmigration crisis: Immigrants, crime, and sovereign power. American University Law Review, vol. 56 (367), Lewis \& Clark Law School Legal Research Paper Series Paper No. 2007-2.

55. Tonry, M. (Ed.). (1997). Ethnicity, crime and immigration. Comparative and cross-national perspectives. Chicago/London: University of Chicago Press.

56. Van der Heijden, P., Cruyff, M., \& Van Houwelingen, H. (2003). Estimating the size of a criminal population from police records using the truncated poisson regression model. Statistica Neerlandica, 57, 289-304.

57. Van der Leun, J. P. (2003). Looking for loopholes: Processes of incorporation of illegal immigrants in the Netherlands. Amsterdam: Amsterdam University Press.

58. Van der Leun, J. P. (2010). Crimmigratie. Apeldoorn/Antwerpen: Maklu (inaugural lecture).

59. Van der Leun, J. P., \& Ilies, M. (2010). The Netherlands: Assessing the irregular population in a restrictive setting. In A. Triandafyllidou (Ed.), Irregular migration in Europe: Myths and realities (pp. 187-206). Farnham: Ashgate.

60. Van der Leun, J. P., \& Kloosterman, R. (2006). Going underground. The labour market position of undocumented immigrants in the Netherlands. Tijdschrift voor Economische en Sociale Geografie, 97 (1), 59-68.

61. Van Kalmthout, A. (2007). Foreigners. In M. Boone \& M. Moerings (Eds.), Dutch prisons (pp. 101125). The Hague: BJU legal Publishers.

62. Van Meeteren, M., Van San, M., \& Engbersen, G. (2008). 'Zonder papieren': Over de positie van irreguliere migranten en de rol van het vreemdelingenbeleid in België. Leuven: Acco.

63. Varsanyi, M. (Ed.). (2010). Taking local control. Immigration policy activism in U.S. cities and states. Stanford: Stanford University Press.

64. Vermeulen, G. (2007). Mutual instrumentalization of criminal and migration law from an EU perspective. European Journal of Migration and Law, 9, 347-361. 
65. Von Lampe, K. (2004). Making the second step before the first: Assessing organized crime. Crime, Law and Social Change, 42, 227-259.

66. Waddington, J., Stenson, K., \& Don, D. (2004). In proportion: Race, and police stops and search. British Journal of Criminology, 44, 889-914.

67. Walters, W. (2006). Border/control. European Journal of Social Theory, 9(2), 187-203.

68. Weenink, A., \& Huisman, S. (2003). Poolse bendes in Nederland; voorlopige bevindingen. Justitiële Verkenningen, 29, 81-91.

69. Wittebrood, K., \& Nieuwbeerta, P. (2006). Een kwart eeuw stijging in geregistreerde criminaliteit. Tijdschrift voor Criminologie, 48, 227-242. 